Pacific Journal of Mathematics

ARCWISE CONNECTIVITY OF SEMI-APOSYNDETIC PLANE 


\title{
ARCWISE CONNECTIVITY OF SEMI-APOSYNDETIC PLANE CONTINUA
}

\author{
Charles L. Hagopian
}

\begin{abstract}
Suppose $M$ is a bounded semi-aposyndetic plane continuum and for any positive real number $\varepsilon$ there are at most a finite number of complementary domains of $M$ of diameter greater than $\varepsilon$. In this paper it is proved that $M$ is arcwise connected.
\end{abstract}

Let $M$ be a continuum (a closed connected point set) and let $x$ and $y$ be distinct points of $M$. If $M$ contains a continuum $H$ and an open set $G$ such that $x \in G \subset H \subset M-\{y\}$, then $M$ is said to be aposyndetic at $x$ with respect to $y$ [4]. $M$ is said to be semi-aposyndetic if for each pair of distinct points $x$ and $y$ of $M, M$ is aposyndetic either at $x$ with respect to $y$ or at $y$ with respect to $x$. In [3] it is proved that every bounded semi-aposyndetic plane continuum which does not have infinitely many complementary domains is arcwise connected. For other results concerning semi-aposyndetic plane continua see [1] and [2].

Let $x$ and $y$ be distinct points of a metric space $S$. A finite collection $\left\{A_{1}, A_{2}, \cdots, A_{m}\right\}$ of sets in $S$ is a chain in $S$ from $x$ to $y$ provided $A_{1}$ contains $x, A_{m}$ contains $y$, and for $i$ and $j$ belonging to $\{1,2, \cdots, m\}, A_{i} \cap A_{j} \neq \phi$ if and only if $|\mathrm{i}-\mathrm{j}| \leqq 1$. If each element of a chain $\mathscr{A}$ has diameter less than $r$ (a positive real number) then $\mathscr{A}$ is said to be an r-chain. Suppose $\mathscr{A}=\left\{A_{1}, A_{2}, \cdots, A_{m}\right\}$ and $\mathscr{B}=$ $\left\{B_{1}, B_{2}, \cdots, B_{n}\right\}$ are chains in $S$ from $x$ to $y$. The chain $\mathscr{B}$ is said to run straight through $\mathscr{A}$ provided the closure of each element of $\mathscr{B}$ is contained in an element of $\mathscr{A}$ and if $B_{i}$ and $B_{k}(1 \leqq i \leqq k \leqq n)$ both lie in an element $A_{s}$ of $\mathscr{A}$, then for each integer $j(i<j<k)$, $B_{j}$ is contained in an element of $\mathscr{A}$ whose intersection with $A_{s}$ is nonvoid.

If $M$ is a bounded plane continuum and for any positive real number $\varepsilon$ there are at most a finite number of complementary domains of $M$ of diameter greater than $\varepsilon$, then $M$ is said to be an $E$-continuum [6, p. 112].

The boundary of a set $A$ is denoted by $\mathrm{Bd} A$.

TheOREM 1. Suppose $M$ is a semi-aposyndetic E-continuum is $S$ (a 2-sphere with metric $\varphi$ ), $U$ is a disk in $S, x$ and $y$ are distinct points which belong to the same component of $M \cap U$, and $V$ is an open disk in $S$ containing $U$. Then for any positive real number $r$ less than both $\varphi(x, y) / 5$ and $\varphi(B d U, B d V) / 5$ there exists an r-chain $\left\{H_{1}, H_{2}, \cdots, H_{n}\right\}(n>3)$ in $S$ from $x$ to $y$ such that for each positive 
integer $i$ less than or equal $n, H_{i}$ is a continuum in $M \cap V$ and $\varphi\left(H_{i}, \mathrm{Bd} V\right)$ is greater than $4 r$.

Proof. Let $G$ be the union of all components of $S-M$ which have diameter less than $r / 3$. Since $M$ is a semi-aposyndetic $E$-continuum, $M \cup G$ is a semi-aposyndetic continuum which does not have infinitely many complementary domains [5, Th. 2 (proof)]. Let $F$ be the $x$-component of $U \cap(M \cup G) . F$ is a semi-aposyndetic continuum in $S$ which does not have infinitely many complementary domains [3, Th. 1] ( $D$ and $M$ in [3] are $S-U$ and $M \cup G$ respectively). Hence $F$ is arcwise connected [3, Th. 2]. Let $A$ be an arc in $F$ from $x$ to $y$. There exists a finite point set $B$ in $A-\{x, y\}$ such that each component of $A-B$ has diameter less than $r / 3$. For each component $C$ of $A-B$, let $G(C)$ be $C$ union all components of $G$ which intersect $C$ and let $Z(C)$ be the boundary (relative to $S$ ) of $G(C)$. For each component $C$ of $A-B$, since the boundary of each component of $G$ is a continuum [6, Th. 2.1, p. 105] and each point of $C$ that is not in $G$ belongs to $Z(C), Z(C)$ is a continuum of diameter less than $r$ in $M$. Let $\mathscr{K}$ be the finite coherent collection of continua $\{Z(C) \mid C$ is a component of $A-B\}$. The points $x$ and $y$ each belong to an element of $\mathscr{C}$ and each element of $\mathscr{C}$ intersects $U$. It follows that any chain from $x$ to $y$ whose elements are members of $\mathscr{K}$ has the specified conditions.

TheoReM 2. If $M$ is a semi-aposyndetic E-continuum, then $M$ is arcwise connected.

Proof. Let $S$ be a 2-sphere which contains $M$ and let $\varphi$ be a distance function on $S$. Let $p$ and $q$ be distinct points of $M$. Define $r_{1}$ to be a positive real number less than both $1 / 8$ and $\varphi(p, q) / 5$ and let $s_{1}=4 r_{1}$. According to Theorem 1 , there exists an $r_{1}$-chain $\left\{H_{1}^{1}\right.$, $\left.H_{2}^{1}, \cdots, H_{n_{1}}^{1}\right\}\left(n_{1}>3\right)$ in $S$ from $p$ to $q$ such that for each positive integer $i$ less than or equal $n_{1}, H_{i}^{1}$ is a continuum in $M$. Let $m_{1}$ be the smallest integer greater than or equal to $\left(n_{1}-1\right) / 2$. There exist a set of $\operatorname{disks}\left\{U_{1}^{1}, U_{1}^{2}, \cdots, U_{m_{1}}^{1}\right\}$ and a set of open disks $\left\{V_{1}^{1}, V_{2}^{1}, \cdots, V_{m_{1}}^{1}\right\}$ such that $\left\{V_{1}^{1}, V_{2}^{1}, \cdots, V_{m_{1}}^{1}\right\}$ is an $s_{1}$-chain in $S$ from $p$ to $q$ and for each positive $i$ less than or equal $m_{1}, H_{2 i-1}^{1} \cup H_{2 i}^{1} \cup H_{2 i+1}^{1} \subset U_{i}^{1} \subset V_{2}^{1}$ (if $n_{1}$ is even, let $\left.H_{n_{1}+1}^{1}=\dot{\phi}\right)$.

Let $\left\{p_{1}^{1}, p_{2}^{1}, \cdots, p_{m_{1}+1}^{1}\right\}$ be a point set such that $p_{1}^{1}=p, p_{m_{1}+1}^{1}=q$, and for each positive integer $i$ less than or equal $m_{1}, p_{i}^{i}$ belongs to $H_{2 i-1}^{1}$. Let $t_{1}$ be the smallest number in the set $\left\{\varphi\left(\mathrm{Bd} U_{i}^{1}, \mathrm{Bd} V_{i}\right) \mid i\right.$ $\left.\leqq m_{1}\right\} \cup\left\{\varphi\left(p_{i}^{1}, p_{\imath+1}^{1}\right) \mid i \leqq m_{1}\right\}$. Let $r_{2}$ be a positive real number less than both $t_{1} / 5$ and $1 / 16$. Define $s^{2}$ to be $4 r_{2}$. For each positive in- 
teger $i$ less than or equal $m_{1}$, there exists an $r_{2}$-chain $\mathscr{C}_{i}$ in $S$ from $p_{i}^{1}$ to $p_{i+1}^{1}$ such that each element of $\mathscr{C}_{i}$ is a continuum in $M \cap V_{i}^{1}$ and at a distance greater than $4 r_{2}$ from $\mathrm{Bd} V_{i}^{1}$ (Theorem 1). There exists an $r_{2}$-chain $\left\{H_{1}^{2}, H_{2}^{2}, \cdots, H_{n_{2}}^{2}\right\}$ in $S$ from $p$ to $q$ whose elements belong to $\bigcup_{i=1}^{m_{1}} \mathscr{C}_{i}$ such that for each positive integer $i$ less than or equal $m_{1}, \mathscr{C}_{i} \cap\left\{H_{1}^{2}, H_{2}^{2}, \cdots, H_{n_{2}}^{2}\right\}$ is a coherent collection. Let $m_{2}$ be the smallest integer greater than or equal to $\left(n_{2}-1\right) / 2$. There exist a set of disks $\left\{U_{1}^{2}, U_{2}^{2}, \cdots, U_{m_{2}}^{2}\right\}$ and a set of open disks $\left\{V_{1}^{2}, V_{2}^{2}, \cdots\right.$, $\left.V_{m_{2}}^{2}\right\}$ such that $\left\{V_{1}^{2}, V_{2}^{2}, \cdots, V_{m_{2}}^{2}\right\}$ is an $s_{2}$-chain in $S$ from $p$ to $q$ and for each positive integer $i$ less than or equal $m_{2}, H_{2 i-1}^{2} \cup H_{2 i}^{2} \cup H_{2 i+1}^{2} \subset$ $U_{i}^{2} \subset V_{i}^{2}$ (if $n_{2}$ is even, let $H_{n_{2}+1}^{2}=\varnothing$ ). Note that $\left\{V_{1}^{2}, V_{2}^{2}, \cdots, V_{m_{2}}^{2}\right\}$ runs straight through $\left\{V_{1}^{1}, V_{2}^{1}, \cdots, V_{m_{1}}^{1}\right\}$.

Continue this process. For $i=3,4,5, \cdots$, there exists a chain $\left\{H_{1}^{i}, H_{2}^{i}, \cdots, H_{n_{i}}^{i}\right\}$ in $S$ from $p$ to $q$ whose elements are continua in $M$, and there exists an $s_{i}$-chain $\left\{V_{1}^{i}, V_{2}^{i}, \cdots, V_{m_{i}}^{i}\right\}\left(s_{i}<1 / 2^{i}\right)$ in $S$ from $p$ to $q$ whose elements are open disks in $S$ such that $\bigcup_{j=2}^{m_{i}} V_{j}^{i}$ contains $\bigcup_{j=1}^{n_{i}} H_{j}^{i}$ and $\left\{V_{1}^{i}, V_{2}^{i} \cdots, V_{m_{2}}^{i}\right\}$ runs straight through $\left\{V_{1}^{i-1}, V_{2}^{i-1}, \cdots\right.$, $\left.V_{m_{i-1}}^{i-1}\right\}$. For each positive integer $i$, let $L_{i}$ be the continuum $\bigcup_{j=1}^{n} H_{j}^{i}$. The limiting set $L$ of the sequence $L_{1}, L_{2}, L_{3}, \cdots$ is a continuum in $M$ containing $p$ and $q$. Note that for each positive integer $i, L$ is contained in $\bigcup_{j=1}^{m_{i}} V_{j}^{i}$.

Let $x$ be a point of $L-\{p, q\}$. For each positive integer $i$, let $V_{j_{i}}^{i}$ be an element of $\left\{V_{1}^{i}, V_{2}^{2}, \cdots, V_{m_{i}}^{2}\right\}$ which contains $x$. Assume without loss of generality that $4<j_{1}<m_{1}-4$. For each positive integer $i$, let $P_{i}$ be $\left\{V_{1}^{i}, V_{2}^{i}, \cdots, V_{j_{i}-4}^{i}\right\}$ and let $F_{i}$ be $\left\{V_{j_{i}+4}^{i}, V_{j_{i}+5}^{i}, \cdots, V_{m_{i}}^{i}\right\}$. Let $P=\bigcup_{i=1}^{\infty}\left(P_{i} \cap L\right)$ and $F=\bigcup_{i=1}^{\infty}\left(F_{i} \cap L\right) . P$ and $F$ are nonempty disjoint relatively open subsets of $L$ and $P \cup F=L-\{x\}$. Hence $x$ is a separating point of $L$. It follows that $L$ has only two nonseparating points. Therefore $L$ is an arc [6, Th. 6.2, p. 54]. Hence $M$ is arcwise connected.

REVARK. Using [3, Th. 1] and Theorem 2 one can easily prove that if $M$ is a semi-aposyndetic $E$-continuum, then $M$ has Jones's cyclic property (that is, if $p$ and $q$ are distinct points of $M$ and no point cuts $p$ from $q$ in $M$, then there exists a simple closed curve lying in $M$ which contains $p$ and $q$ ).

\section{REFERENCES}

1. C.L. Hagopian, Arc-wise connectedness of semi-aposyndetic plane continua, to appear in Trans. Amer. Math. Soc., 158 (1971).

2. - An arc theorem for plane continua, soon to appear in Ill. J. of Math.

3. - A class of arcwise connected continua, soon to appear in Proc. Amer. Math. Soc. 
4. F. B. Jones, Aposyndetic continua and certain boundary problems, Amer. J. Math., 63 (1941), 545-553.

5. - A characterization of a semi-locally-connected plane continuum, Bull. Amer. Math. Soc., 53 (1947), 170-175.

6. G. T. Whyburn, Analytic topology, Amer. Math. Soc. Colloquium Publications, vol. 28, Rhode Island, 1963 (Revised edition).

Received December 4, 1970 and in revised form April 28, 1971.

Sacramento State College 


\title{
PACIFIC JOURNAL OF MATHEMATICS
}

\author{
EDITORS
}

\author{
H. SAMelson \\ Stanford University \\ Stanford, California 94305 \\ C. R. HoBBy \\ University of Washington \\ Seattle, Washington 98105
}

J. DugunduI

Department of Mathematics

University of Southern California

Los Angeles, California 90007

RICHARD ARENS

University of California

Los Angeles, California 90024

\section{ASSOCIATE EDITORS}

\author{
E. F. BeCKENBACH
}

B. H. NEUMANN

F. WoLF

K. YOSHIDA

\section{SUPPORTING INSTITUTIONS}

\author{
UNIVERSITY OF BRITISH COLUMBIA \\ CALIFORNIA INSTITUTE OF TECHNOLOGY \\ UNIVERSITY OF CALIFORNIA \\ MONTANA STATE UNIVERSITY \\ UNIVERSITY OF NEVADA \\ NEW MEXICO STATE UNIVERSITY \\ OREGON STATE UNIVERSITY \\ UNIVERSITY OF OREGON \\ OSAKA UNIVERSITY \\ UNIVERSITY OF SOUTHERN CALIFORNIA
}

\author{
STANFORD UNIVERSITY \\ UNIVERSITY OF TOKYO \\ UNIVERSITY OF UTAH \\ WASHINGTON STATE UNIVERSITY \\ UNIVERSITY OF WASHINGTON \\ AMERICAN MATHEMATICAL SOCIETY \\ CHEVRON RESEARCH CORPORATION \\ NAVAL WEAPONS CENTER
}

The Supporting Institutions listed above contribute to the cost of publication of this Journal, but they are not owners or publishers and have no responsibility for its content or policies.

Mathematical papers intended for publication in the Pacific Journal of Mathematics should be in typed form or offset-reproduced, (not dittoed), double spaced with large margins. Underline Greek letters in red, German in green, and script in blue. The first paragraph or two must be capable of being used separately as a synopsis of the entire paper. The editorial "we" must not be used in the synopsis, and items of the bibliography should not be cited there unless absolutely necessary, in which case they must be identified by author and Journal, rather than by item number. Manuscripts, in duplicate if possible, may be sent to any one of the four editors. Please classify according to the scheme of Math. Rev. Index to Vol. 39. All other communications to the editors should be addressed to the managing editor, Richard Arens, University of California, Los Angeles, California, 90024.

50 reprints are provided free for each article; additional copies may be obtained at cost in multiples of 50 .

The Pacific Journal of Mathematics is published monthly. Effective with Volume 16 the price per volume (3 numbers) is $\$ 8.00$; single issues, $\$ 3.00$. Special price for current issues to individual faculty members of supporting institutions and to individual members of the American Mathematical Society: $\$ 4.00$ per volume; single issues $\$ 1.50$. Back numbers are available.

Subscriptions, orders for back numbers, and changes of address should be sent to Pacific Journal of Mathematics, 103 Highland Boulevard, Berkeley, California, 94708.

PUBLISHED BY PACIFIC JOURNAL OF MATHEMATICS, A NON-PROFIT CORPORATION

Printed at Kokusai Bunken Insatsusha (International Academic Printing Co., Ltd.), 7-17, Fujimi 2-chome, Chiyoda-ku, Tokyo, Japan. 


\section{Pacific Journal of Mathematics}

\section{Vol. 37, No. $3 \quad$ March, 1971}

Mohammad Shafqat Ali and Marvin David Marcus, On the degree of the

minimal polynomial of a commutator operator ................ 561

Howard Anton and William J. Pervin, Integration on topological

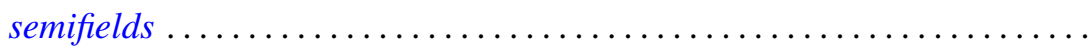

Martin Bartelt, Multipliers and operator algebras on bounded analytic

functions .................................... 575

Donald Earl Bennett, Aposyndetic properties of unicoherent continua ...... 585

James W. Bond, Lie algebras of genus one and genus two ............. 591

Mario Borelli, The cohomology of divisorial varieties ............... 617

Carlos R. Borges, How to recognize homeomorphisms and isometries ....... 625

J. C. Breckenridge, Burkill-Cesari integrals of quasi additive interval

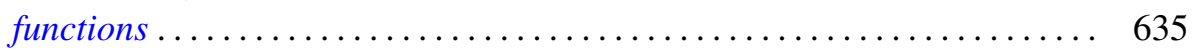

J. Csima, A class of counterexamples on permanents ................ 655

Carl Hanson Fitzgerald, Conformal mappings onto $\omega$-swirly domains . . . . . . 657

Newcomb Greenleaf, Analytic sheaves on Klein surfaces .............. 671

G. Goss and Giovanni Viglino, C-compact and functionally compact

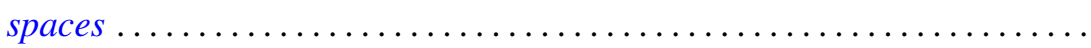

Charles Lemuel Hagopian, Arcwise connectivity of semi-aposyndetic plane

continua ..................................... 683

John Harris and Olga Higgins, Prime generators with parabolic limits ...

David Michael Henry, Stratifiable spaces, semi-stratifiable spaces, and their

relation through mappings .......................

Raymond D. Holmes, On contractive semigroups of mappings ........... 701

Joseph Edmund Kist and P. H. Maserick, BV-functions on semilattices ....... 711

Shûichirô Maeda, On point-free parallelism and Wilcox lattices ........... 725

Gary L. Musser, Linear semiprime $(p ; q)$ radicals ................. 749

William Charles Nemitz and Thomas Paul Whaley, Varieties of implicative

semilattices..................................... 759

Jaroslav Nešetřil, A congruence theorem for asymmetric trees ............ 771

Robert Anthony Nowlan, A study of $H$-spaces via left translations .......... 779

Gert Kjærgaard Pedersen, Atomic and diffuse functionals on a $C^{*}$-algebra ... 795

Tilak Raj Prabhakar, On the other set of the biorthogonal polynomials

suggested by the Laguerre polynomials...

801

Leland Edward Rogers, Mutually aposyndetic products of chainable

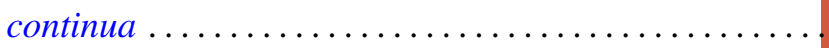

Frederick Stern, An estimate for Wiener integrals connected with squared

error in a Fourier series approximation.

Leonard Paul Sternbach, On k-shrinking and k-boundedly complete basic

sequences and quasi-reflexive spaces .................... 817

Pak-Ken Wong, Modular annihilator $A^{*}$-algebras ........ 